\title{
Cryopreservation increases coating of bull sperm by seminal plasma binder of sperm proteins BSP1, BSP3, and BSP5
}

\author{
Florencia Ardon and Susan S Suarez \\ Department of Biomedical Sciences, College of Veterinary Medicine, T5-002B Veterinary Research Tower, \\ Cornell University, Ithaca, New York 14853, USA \\ Correspondence should be addressed to S S Suarez; Email: sss7@cornell.edu
}

\begin{abstract}
Artificial insemination with frozen semen allows affordable, worldwide dissemination of gametes with superior genetics. Nevertheless, sperm are damaged by the cryopreservation process. Elucidating the molecular effects of cryopreservation on sperm could suggest methods for improving fertility of frozen/thawed semen. This study was undertaken to examine the effect of cryopreservation on the coating of sperm by binder of sperm (BSP) proteins in seminal plasma. BSP proteins are secreted by the seminal vesicles and coat the surface of sperm by partially intercalating into the outer leaflet of the sperm plasma membrane. The BSP proteins are known to play roles in the formation of the oviductal sperm storage reservoir and in sperm capacitation. We investigated the effects of cryopreservation on the sperm BSP protein coat using Bovipure to separate live sperm from extended semen and then assaying the amounts of BSP proteins on sperm using quantitative western blotting with custom-made antibodies against unique sequences of each BSP protein. Greater amounts of all three BSP proteins (BSP1, BSP3, and BSP5) were detected on frozen/thawed sperm than on fresh sperm. Furthermore, the reduction of BSP3 from 15 to $13 \mathrm{kDa}$ in mass, which occurs during incubation of sperm under mild capacitating conditions, was enhanced by cryopreservation. We concluded that freezing alters the BSP protein coating on sperm, which could account in part for reduced fertility of cryopreserved semen samples. Reproduction (2013) $146111-117$
\end{abstract}

\section{Introduction}

Artificial insemination with cryopreserved semen is used to breed the majority of dairy cows in the developed world (FAO 2011). The cryopreservation process consists of several steps, including an initial dilution of the original ejaculate in extender, cooling to $4{ }^{\circ} \mathrm{C}$, further dilution in extender containing glycerol, freezing, storage, and thawing of sperm (Hammerstedt et al. 1990). The extender normally contains either milk or egg yolk, which, along with glycerol, protects the sperm from the severe cryodamage that could arise from the formation of ice crystals during the process of freezing down to $-196{ }^{\circ} \mathrm{C}$ (Parks \& Graham 1992, Watson 1995, Bergeron \& Manjunath 2006), the temperature at which the semen is stored. Sperm are also stressed during cryopreservation by changes in temperature and osmotic pressure (Hammerstedt et al. 1990).

Cryopreservation is known to damage sperm in a variety of ways. Cryopreserved bull sperm show ultrastructural damage of the plasma membrane (PonsRejraji et al. 2009, Forero-Gonzalez et al. 2010) and cytoskeleton (Felipe-Pérez et al. 2011), increased levels of intracellular Ca ${ }^{2+}$ (Bailey \& Buhr 1993, Pons-Rejraji et al. 2009) and $\mathrm{K}^{+}$(Blässe et al. 2012), redistribution of plasma membrane proteins, reduced tolerance to hypotonic stress, and a decrease in intracellular $\mathrm{pH}$ and cAMP (Pons-Rejraji et al. 2009, Blässe et al. 2012). The sub-lethal damage and modifications induced by cryopreservation translate into a shortened life span (Bailey et al. 2000). Additionally, immediately after thawing, a large proportion of the cryopreserved sperm may show the chlortetracycline staining pattern that is typical of capacitated sperm (Cormier \& Bailey 2003, Pons-Rejraji et al. 2009). Furthermore, cryopreserved sperm have been deemed to be more sensitive to capacitating agents (Watson 1995, Cormier \& Bailey 2003, Pons-Rejraji et al. 2009). Here, we present evidence for an additional effect of cryopreservation, namely modification of the coat of binder of sperm (BSP) proteins on sperm.

BSP proteins are the major secretory products of the bovine seminal vesicles and they bind to sperm with which they come into contact (Desnoyers \& Manjunath 1992, Manjunath et al. 2009). The binding process is very rapid; e.g. the half time for BSP1 binding to sperm is calculated as <1 s (Müller et al. 1998). Homologs of bovine BSP proteins have been identified in several other mammalian species including humans (Lefebvre et al. 2009), buffalo (Arangasamy et al. 2005), bison (Boisvert et al. 2004), boar, stallions (Calvete et al. 1997), rams (Barrios et al. 2005, Bergeron et al. 2005), goats 
(Villemure et al. 2003), and mice (Plante et al. 2012). In cattle, three BSP proteins, BSP1 (previously known as PDC109), BSP3 (BSP-A3), and BSP5 (BSP-30 kDa), have been found to play a role in fertilization (Manjunath et al. 2009). Each one of these BSP proteins is composed of a unique $\mathrm{N}$-terminal domain followed by two fibronectin type II domains (Calvete et al. 1996) that contain heparin and phospholipid binding sites (Wah et al. 2002). The $\mathrm{N}$-terminal domains of the three BSP proteins differ considerably (Seidah et al. 1987, Calvete et al. 1996), as do the patterns of molecular surface charges in the fibronectin type II domains, which contain the binding sites of the BSP proteins for the sperm plasma membrane and the oviductal receptors (Gwathmey et al. 2006).

BSP proteins promote sperm binding to oviductal epithelial cells. This binding plays a role in the establishment of a sperm reservoir in the lower oviduct, where the viability and motility of the sperm are preserved (Pollard et al. 1991, Gwathmey et al. 2006, Suarez 2007). The reservoir is also believed to play a role in selection of high-quality sperm for fertilization (Thomas et al. 1994, Lefebvre \& Suarez 1996, Gualtieri \& Talevi 2000, 2003, Ardón et al. 2008). The BSP proteins seem crucial for the formation of the reservoir in cattle because sperm collected from the epididymis, which have not yet been exposed to BSP proteins, bind very poorly to the oviductal epithelium. If, however, any one of the three BSP proteins is added to epididymal sperm, their ability to bind to the oviductal epithelium increases substantially (Gwathmey et al. 2006). This observation indicated that different BSP proteins need not interact in order to promote epithelial binding.

The aforementioned differences among the three BSP proteins could translate into different binding affinities for oviductal epithelium, as well as differing detachment kinetics. Furthermore, the BSP coating of sperm is modified during capacitation in vitro, even under minimal capacitation conditions (Hung \& Suarez 2012). Capacitated sperm lose binding affinity for the oviductal epithelium (Lefebvre \& Suarez 1996). Therefore, changes in the BSP protein coat of sperm could allow for a gradual release of sperm from the reservoir.

The positive effects of BSPs could peak at certain concentrations and decline thereafter. Moura et al. (2006) reported that, while low amounts of BSP5 in semen enhanced bull fertility, high amounts decreased it. Several other field studies have found a negative relationship between bull fertility and high amounts of BSP proteins in the semen (BSP1: D'Amours et al. 2010, Lessard et al. 2011; BSP3: Roncoletta et al. 2006). BSP proteins bind to caseins from milk when the mixtures are not frozen, so it is possible that these extender components could interfere with the BSP protein coating of sperm (Bergeron et al. 2007). Therefore, this study was designed to test the hypothesis that cryopreservation modifies the BSP protein coat of bull sperm.

\section{Materials and methods}

\section{Reagents and media}

Chemicals used for routine procedures were purchased from Sigma-Aldrich, unless otherwise specified. Tyrode albumin lactate pyruvate (TALP, Parrish et al. (1988)), a modified Tyrodebalanced salt solution, was used for fresh semen dilution and washing of both fresh and cryopreserved sperm. TALP medium consisted of $99 \mathrm{mM} \mathrm{NaCl}, 3.1 \mathrm{mM} \mathrm{KCl}, 25 \mathrm{mM} \mathrm{NaHCO}$, $0.39 \mathrm{mM} \mathrm{NaH}{ }_{2} \mathrm{PO}_{4}, 10 \mathrm{mM}$ HEPES-free acid, $2 \mathrm{mM} \mathrm{CaCl}$, $1.1 \mathrm{mM} \mathrm{MgCl} 2,25.4 \mathrm{mM}$ sodium lactate, $0.11 \mathrm{mg} / \mathrm{ml}$ sodium pyruvate, $5 \mu \mathrm{g} / \mathrm{ml}$ gentamicin, and $6 \mathrm{mg} / \mathrm{ml} \mathrm{BSA}$ (Fraction $\mathrm{V}$; Calbiochem, La Jolla, CA, USA), with a pH of 7.4 and $300 \mathrm{mOsm} / \mathrm{kg}$. PBS was used for washing all sperm before protein extraction. It consisted of $1.9 \mathrm{NaH}_{2} \mathrm{PO}_{4}, 8.1 \mathrm{mM}$ $\mathrm{Na}_{2} \mathrm{HPO}_{4}$, and $154 \mathrm{mM} \mathrm{NaCl}$, with a $\mathrm{pH}$ of 7.36. SDS sample buffer (Laemmli 1970) consisted of $125 \mathrm{mM}$ Tris- $\mathrm{HCl}, \mathrm{pH} 6.8$, 69.4 mM SDS (Fisher Scientific, Pittsburgh, PA, USA), $1 \mathrm{mg} / \mathrm{ml}$ bromophenol blue, and $10 \%$ glycerol. Tris-buffered salineTween 20 (TBST) contained $100 \mathrm{mM}$ Tris, $154 \mathrm{mM} \mathrm{NaCl}$, and $0.1 \%$ Tween 20, $\mathrm{pH}$ 7.5. Precision plus protein standards (kaleidoscope) were from Bio-Rad.

\section{Sperm processing}

Fresh semen ( $n=10$ bulls) was kindly provided by Genex Cooperative, Inc. (Ithaca, NY, USA). Shortly after collection, two aliquots from each ejaculate were obtained, each containing a volume equivalent to one billion sperm, as determined by means of a spectrophotometer at Genex Cooperative, Inc. One aliquot was diluted in $5 \mathrm{ml}$ milk extender and the other in the same amount of TALP medium. The samples were transported to the laboratory in a $38.5^{\circ} \mathrm{C}$ warm water jacket. To standardize the contact time with milk extender or TALP medium and because transportation times varied, the total time sperm were kept in either media was set to $1 \mathrm{~h}$. Then, seminal plasma, extender, and dead sperm were removed from live sperm by density gradient centrifugation (300 $\mathrm{g}$ for $25 \mathrm{~min}$ ) through two layers (40-80\%) of BoviPure (Spectrum Technologies, Inc., Healdsburg, CA, USA); the sperm pellet was then washed in $3 \mathrm{ml} \mathrm{TALP}$ (300 g, $5 \mathrm{~min}$ ). Sperm were resuspended in $1 \mathrm{ml}$ TALP medium. We tested whether unbound BSP proteins could pass through the Bovipure gradient and could not detect any at the bottom of the tube.

The same process was used to isolate live sperm from frozen/thawed extended semen from six other bulls. The straws had been diluted in milk extender according to the standard procedures followed at Genex Cooperative, Inc., which are described by Kaproth et al. (2005). Straws from at least three separate ejaculates from each bull were used. To minimize variation due to between-bull differences for the frozen sperm, for every experiment, a mix of proteins was prepared, which contained a proportional amount of proteins from each of four bulls. Fresh sperm samples were kept unmixed, to allow for within-bull comparisons. Fresh and frozen/thawed sperm concentration was determined using an improved Neubauer hemocytometer. Visual motility estimation of all samples was conducted using bright field microscopy at $100 \times$ magnification on a warm stage $\left(38.5^{\circ} \mathrm{C}\right)$. Samples were used when 
final motility (i.e. after gradient density centrifugation and washing) was higher than $85 \%$.

\section{Gel electrophoresis and western blot}

SDS-PAGE of sperm proteins was performed according to the method developed by Laemmli (1970). Suspensions of live, motile sperm in TALP were centrifuged at $12000 \mathrm{~g}$ for $10 \mathrm{~min}$. Sperm were washed once more with PBS (12 $000 \boldsymbol{g}$ for $10 \mathrm{~min}$ ). The supernatant was removed and the sperm pellets were lysed in SDS sample buffer and boiled for $5 \mathrm{~min}$, then centrifuged for $10 \mathrm{~min}$ at $12000 \mathrm{~g}$ to remove cellular material. The supernatants containing the protein extracts were frozen at $-20^{\circ} \mathrm{C}$ until further processing. Seminal plasma from fresh semen was isolated from sperm by centrifugation through 1.5 centrifuge tube filters (Costar Spin-X, $0.22 \mu \mathrm{m}$ pore; Corning, Inc., Corning, NY, USA). The seminal plasma was diluted 1:1000 in SDS sample buffer and frozen $\left(-20^{\circ} \mathrm{C}\right)$ in $10 \mu$ l aliquots until use. Immediately before being subjected to gel electrophoresis, sperm and seminal plasma proteins were boiled for $5 \mathrm{~min}$ in the presence of $5 \% \quad \beta$-mercaptoethanol (GE Healthcare Biosciences, Pittsburgh, PA, USA). Proteins corresponding to two million (BSP1) or five million (BSP3 and BSP5) sperm per sample were resolved on $18 \%$ polyacrylamide gels (ProtoGel, National Diagnostics, Atlanta, GA, USA) and electroblotted to PVDF membranes (Immobilon transfer membrane, Millipore Co., Bedford, MA, USA) using the method described by Towbin et al. (1979). The membranes were blocked (Starting Block T20 (TBS) Blocking Buffer, Thermo Fisher Scientific, Inc., Rockford, IL, USA) for $1 \mathrm{~h}$ at room temperature, followed by overnight incubation at $4{ }^{\circ} \mathrm{C}$ with custom-made antibodies against peptides in the N-terminal domains of BSP1, BSP3, and BSP5 (30, $350 \mathrm{ng} / \mathrm{ml}$, and $5.26 \mathrm{mg} / \mathrm{ml}$, respectively; GenScript, Piscataway, NJ, USA; Fig. 1) and a $\beta$-tubulin antibody (20 ng/ $\mathrm{ml}$; DSHB, University of lowa, lowa City, IA, USA) to calibrate the loading of each lane. After washing three times in TBST, membranes were incubated for $1 \mathrm{~h}$ at room temperature with HRP-conjugated goat anti-mouse IgG for the $\beta$-tubulin antibody (125 ng/ml; Millipore Co.) and HRP-conjugated goat anti-rabbit IgG (500 ng/ml; Sigma-Aldrich) for the BSP protein antibodies. The protein bands were visualized using chemiluminescence (Super Signal West Pico Chemiluminescence Substrate; Thermo Fisher Scientific, Inc.) and the Bio-Rad ChemiDoc XRS+ imaging system (Bio-Rad).

\section{Statistical analysis}

The intensities of the protein bands on the western blots were analyzed using Bio-Rad ImageLab Software (Bio-Rad) according to the company's recommendations. Briefly, the background was subtracted using a disc size of $10 \mathrm{~mm}$ along each lane. The width of each band was set based on the lane profile, ensuring that all the area above the background level was enclosed by each band. Using the relative quantity tool, the relative intensity of each BSP protein band was calculated using the $\beta$-tubulin band within the same lane as the reference band. Means \pm S.E.M. are shown for each BSP protein relative intensity value. Data were analyzed on SAS, using a mixed model generalized linear model (GLM) and Tukey's post hoc comparisons. Family-wise $P$ values $<0.05$ (translating into $P<0.016$ per comparison) were considered significant.

\section{Results}

For these experiments, it was critical to separate the live sperm from dead sperm and seminal plasma. Amounts of BSP proteins on dead sperm would not be biologically meaningful and contamination from any seminal plasma could significantly skew the amounts detected because the amounts present in seminal plasma are so great (BSP1, $31 \mathrm{mg} / \mathrm{ml}$; BSP3, $3 \mathrm{mg} / \mathrm{ml}$; and BSP5, $4 \mathrm{mg} / \mathrm{ml}$ (Nauc \& Manjunath 2000)). Therefore, centrifugation through a step gradient of Bovipure was used to isolate live sperm from seminal plasma.

For BSP1, two closely associated bands were detected, representing the two glycosylation isoforms. They were lumped together for analysis because they were too close together to assess individually. The amount of BSP1 detected in frozen/thawed sperm was greater $(P<0.05)$ than in fresh sperm diluted in milk extender or TALP medium; however, the amount of BSP1 detected in fresh sperm diluted in milk extender was lower $(P<0.05)$ than in fresh sperm diluted in TALP medium (Fig. 2).

Two protein bands of BSP3 were detected, one of $15 \mathrm{kDa}$, present in seminal plasma and sperm, and one of $13 \mathrm{kDa}$, detected on sperm but not in seminal plasma (Fig. 3). For both the 15 and 13 kDa bands, the amount of the BSP3 detected in frozen/thawed sperm was greater

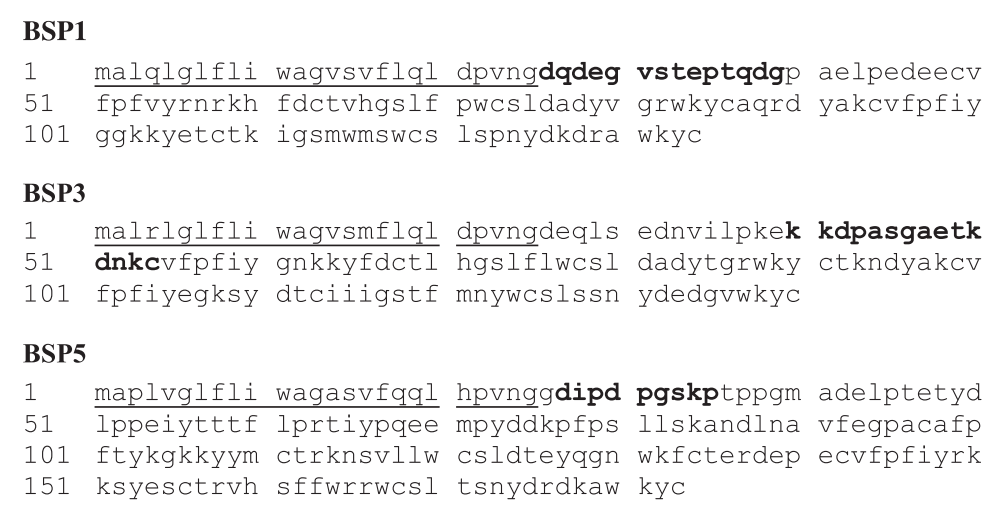

\section{BSP5}

1 maplvglfli wagasvfqql hpvnggdipd pgskptppgm adelptetyd 51 lppeiytttf lprtiypqee mpyddkpfps llskandlna vfegpacafp 101 ftykgkkyym ctrknsvllw csldteyqgn wkfcterdep ecvfpfiyrk 151 ksyesctrvh sffwrrwcsl tsnydrdkaw kyc

Figure 1 BSP1, BSP3, and BSP5 sequences. The antibodies were produced based on unique peptides from the $\mathrm{N}$-terminal domain from each of the BSPs (marked in bold). The putative signal peptides for each BSP are underlined. Accession numbers: BSP1, NP_001001145.1; BSP3 NP_777265.1; and BSP5, NP_777267.1. 

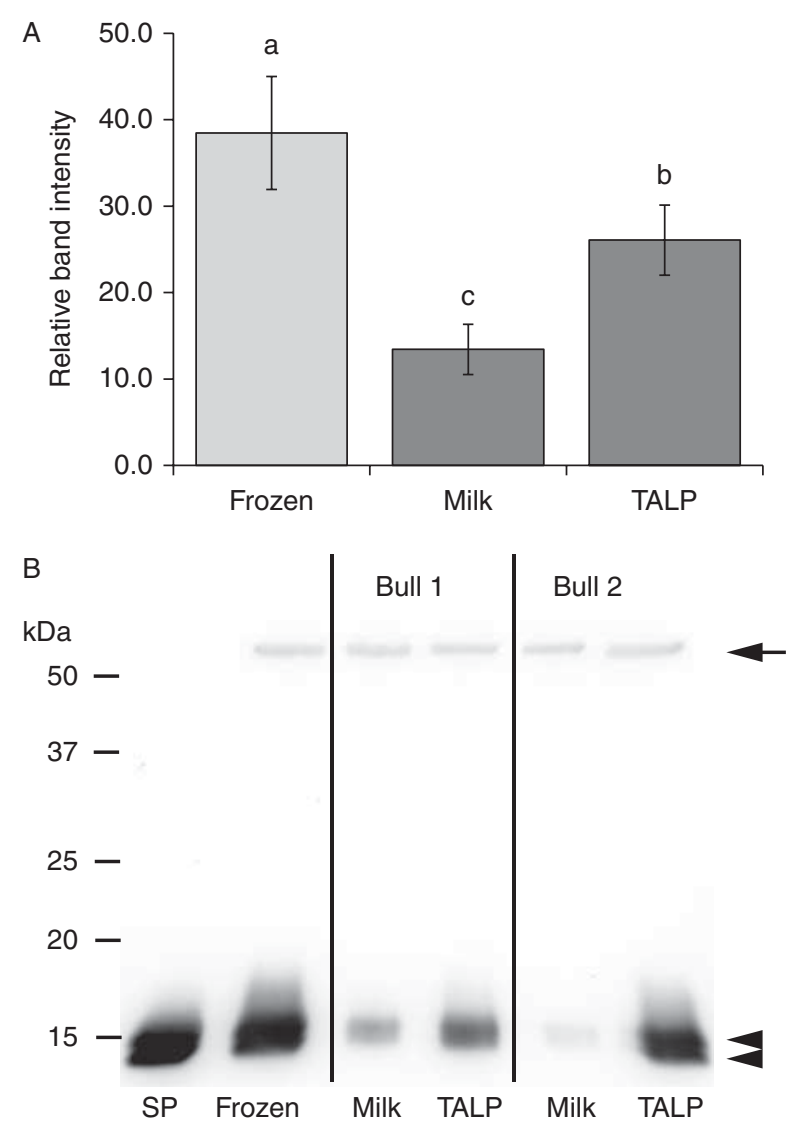

Figure 2 Amount of BSP1 detected on live sperm. (A) Relative band intensities of BSP1 (means \pm s.E.M.; $n=10$ ). The intensity of each BSP1 band was normalized to that of the $\beta$-tubulin band within the same lane. Different letters indicate significant family-wise differences $(P<0.05)$. (B) Representative western blot of BSP1 in sperm extracts from two of the bulls. The arrow indicates the band of $\beta$-tubulin; arrowheads indicate the two glycosylation isoforms of BSP1, which were merged for analysis. Frozen, sperm cryopreserved in milk extender; milk, fresh sperm diluted in milk extender; TALP, fresh sperm diluted in TALP; SP, seminal plasma, diluted 1:1000, used as a positive control.

$(P<0.05)$ than that in fresh sperm diluted in milk extender or TALP medium, while no differences were detected between the amounts in fresh sperm diluted in milk extender and in fresh sperm diluted in TALP medium (Fig. 3).

More BSP5 $(30 \mathrm{kDa})$ was detected in frozen sperm samples than in fresh sperm diluted in either milk extender or TALP medium $(P<0.05)$. No difference was detected between the amount of BSP5 in fresh sperm diluted in milk extender and in TALP medium (Fig. 3).

\section{Discussion}

These findings indicate that freezing and/or thawing enhances the binding of BSP1, BSP3, and BSP5 to sperm. BSP1 levels were higher on sperm after freezing and thawing, despite the observation that BSP1 levels were lower on fresh sperm when semen was diluted in milk extender rather than TALP medium. The finding that dilution in milk extender reduces BSP1 on sperm is in agreement with the findings of Bergeron et al. (2007); however, it was surprising that BSP1 levels were higher on milk-extended frozen/thawed sperm than on fresh sperm.

For 15 and $13 \mathrm{kDa}$ BSP3, as well as for BSP5, dilution in milk extender did not affect binding any differently than dilution in TALP medium; however, freezing increased association of these BSP proteins with sperm. It should be noted that the magnitude of dilution in milk extender was higher in the commercially prepared cryopreserved samples than in fresh sperm, i.e. 1:5 dilution for fresh semen vs up to 1:22 for commercial straws (Genex Cooperative, Inc., personal communication). For this reason, the increased association of the BSP proteins with cryopreserved sperm was particularly surprising.

The increased amount of the $13 \mathrm{kDa}$ band of BSP3 detected in frozen/thawed sperm was an unexpected finding. The appearance of the $13 \mathrm{kDa}$ band had been previously detected on samples from fresh sperm only after they had been incubated under capacitating conditions (Hung \& Suarez 2012). There is evidence that this $13 \mathrm{kDa}$ BSP3 is a product of the cleavage of the $15 \mathrm{kDa}$ BSP3 by a sperm surface protease (Hung \& Suarez 2012). Further research is necessary to elucidate how and when the $15 \mathrm{kDa}$ BSP3 is cleaved during freezing and thawing.

There are some possible explanations for the increased amount of BSP proteins on frozen-thawed sperm. First of all, it is likely that additional BSP protein binding sites could become available on sperm due to modifications in the plasma membrane induced by cryopreservation. BSP1 and BSP3 bind specifically to choline phospholipids (PC), which are localized on the outer leaflet of the sperm plasma membrane, while BSP5 binds preferentially to PC, but also to phosphatidylserine (PS) and other membrane phospholipids (Desnoyers \& Manjunath 1992). PS is mostly restricted to the inner leaflet but translocates to the outer leaflet during cryopreservation (Vadnais \& Althouse 2011). The transfer could allow BSP5 to bind to PS in addition to PC. Furthermore, other potential BSP protein binding sites could become available due to loss of other sperm surface proteins during the cryopreservation process (Ollero et al. 1998). Secondly, during freezing, proteins are subjected to stresses that are known to lead to denaturation. These stresses include changes in $\mathrm{pH}$ and an increase in solute concentration (Cao et al. 2003). Such changes could disrupt the interaction of BSP proteins with casein micelles in milk extender reported by Nauc \& Manjunath (2000), releasing them to interact with sperm. It is necessary to continue this line of investigation to fully understand the mechanism that leads to an increase in BSP proteins on frozen/thawed sperm. 



Figure 3 Amount of BSP3 and BSP5 detected on live sperm. (A) Relative band intensities of 15 kDa BSP3 (means \pm s.E.M.; $n=10$ ). The intensity of each $15 \mathrm{kDa}$ BSP3 band was normalized to that of the $\beta$-tubulin band within the same lane. Different letters indicate significant family-wise differences $(P<0.05)$. (B) Relative band intensities of $13 \mathrm{kDa}$ BSP3 (means \pm s.E.m.; $n=10$ ). The intensity of each $13 \mathrm{kDa}$ BSP3 band was normalized to that of the $\beta$ tubulin band within the same lane. Different letters indicate significant family-wise differences $(P<0.05)$. (C) Relative band intensities of BSP5 (means \pm S.E.M.; $n=10$ ). The intensity of each BSP5 band was normalized to that of the $\beta$-tubulin band within the same lane. Different letters indicate significant family-wise differences $(P<0.05)$. (D) Representative western blot of BSP3 and BSP5 in sperm extracts from two of the bulls. The arrow indicates the band of $\beta$-tubulin; arrowheads indicate BSP5 at about $30 \mathrm{kDa}$ and the two bands of BSP3 at 15 and $13 \mathrm{kDa}$. Frozen, sperm cryopreserved in milk extender; milk, fresh sperm diluted in milk extender; TALP, fresh sperm diluted in TALP; SP, seminal plasma, diluted 1:1000, used as a positive control.

Increased BSP proteins on sperm could significantly affect sperm function. BSP proteins play a crucial role in the formation of the oviductal sperm reservoir (Gwathmey et al. 2006), which serves to store sperm and reduce the chances of polyspermic fertilization (Hunter 1973). This is of paramount importance: for fertilization to be successful, functional, competent gametes must meet at the site of fertilization at the right time (Töpfer-Petersen et al. 2002). Sperm coated with excess amounts of one or more of the three BSP proteins might not be released from the reservoir in a timely manner.

BSP proteins also play a role in capacitation (Lane et al. 1999, Manjunath \& Thérien 2002); therefore, it is possible that excess binding of BSPs to sperm would modify the timing of capacitation, thereby reducing the chance that capacitated sperm would be available to fertilize oocytes during the small window of time when fertilization is optimal.

A detrimental effect of excess BSP proteins on sperm has been reported in a number of field studies. Moura et al. (2006), for instance, found a quadratic relationship between BSP5 and fertility, such that, within a low range of concentrations, greater amounts of BSP5 in semen were related to higher bull fertility, but the relationship reversed at a higher range of concentrations. D'Amours et al. (2010) reported higher levels of BSP1 in low-fertility bulls than in high-fertility bulls. In the same study, BSP1 was also negatively correlated with sperm functionality and more BSP1 protein was detected in immotile sperm. Lessard etal. (2011) found that the BSP1 levels on sperm from an infertile bull were higher than those of his sire. Roncoletta et al. (2006) reported that the levels of BSP3 were higher in lower fertility Nelore bulls. The field studies provide strong indication that the level of BSP protein coating on sperm plays a crucial role for fertilization in vivo.

Whereas BSP proteins are required for sperm to bind to oviductal epithelium in the storage reservoir, excess BSP proteins seem to exert a negative effect on the fertilization capacity of sperm. Further research is needed to fully understand the effect of an increased BSP protein coat on sperm function. It is also important to determine why cryopreservation enhances the binding of BSP proteins to sperm. Such knowledge would help modify the composition of media and/or the freezing procedures in order to prevent excess binding of BSP proteins to sperm. It could also help to fine-tune the timing of insemination, with the ultimate goal of increasing the fertilization rates of inseminated cows.

\section{Declaration of interest}

The authors declare that there is no conflict of interest that could be perceived as prejudicing the impartiality of the research reported. 


\section{Funding}

This project was supported by the National Research Initiative Competitive grant no. 2008-35203-19031 from the USDA National Institute of Food and Agriculture and by Genex Cooperative, Inc. (Shawano, WI, USA).

\section{Acknowledgements}

Bull semen and extender were generously provided by Genex Cooperative, Inc. (Ithaca, NY, USA). The authors are grateful to Jing Yang, from the Cornell Statistical Consulting Unit, for statistical advice.

\section{References}

Arangasamy A, Singh LP, Ahmed N, Ansari MR \& Ram GC 2005 Isolation and characterization of heparin and gelatin binding buffalo seminal plasma proteins and their effect on cauda epididymal spermatozoa. Animal Reproduction Science 90 243-254. (doi:10.1016/j.anireprosci. 2004.12.014)

Ardón F, Helms D, Sahin E, Bollwein H, Töpfer-Petersen E \& Waberski D 2008 Chromatin-unstable boar spermatozoa have little chance of reaching oocytes in vivo. Reproduction 135 461-470. (doi:10.1530/ REP-07-0333)

Bailey JL \& Buhr MM $1993 \quad \mathrm{Ca}^{2+}$ regulation by cryopreserved bull spermatozoa in response to A23187. Cryobiology 30 470-481. (doi:10.1006/cryo.1993.1048)

Bailey JL, Bilodeau JF \& Cormier N 2000 Semen cryopreservation in domestic animals: a damaging and capacitating phenomenon. Journal of Andrology 21 1-7. (doi:10.1002/j.1939-4640.2000.tb03268.x)

Barrios B, Fernández-Juan M, Muiño-Blanco T \& Cebrián-Pérez JA 2005 Immunocytochemical localization and biochemical characterization of two seminal plasma proteins that protect ram spermatozoa against cold shock. Journal of Andrology 26 539-549. (doi:10.2164/jandrol.04172)

Bergeron A \& Manjunath P 2006 New insights towards understanding the mechanisms of sperm protection by egg yolk and milk. Molecular Reproduction and Development 73 1338-1344. (doi:10.1002/mrd. 20565)

Bergeron A, Villemure M, Lazure C \& Manjunath P 2005 Isolation and characterization of the major proteins of ram seminal plasma. Molecular Reproduction and Development 71 461-470. (doi:10.1002/mrd.20310)

Bergeron A, Brindle Y, Blondin P \& Manjunath P 2007 Milk caseins decrease the binding of the major bovine seminal plasma proteins to sperm and prevent lipid loss from the sperm membrane during sperm storage. Biology of Reproduction 77 120-126. (doi:10.1095/biolreprod. 106.058248)

Blässe AK, Oldenhof $H$, Ekhlasi-Hundrieser $M$, Wolkers WF, Sieme H \& Bollwein H 2012 Osmotic tolerance and intracellular ion concentrations of bovine sperm are affected by cryopreservation. Theriogenology $\mathbf{7 8}$ 1312-1320. (doi:10.1016/j.theriogenology.2012.05.029)

Boisvert M, Bergeron A, Lazure C \& Manjunath P 2004 Isolation and characterization of gelatin-binding bison seminal vesicle secretory proteins. Biology of Reproduction 70 656-661. (doi:10.1095/biolreprod.103.023069)

Calvete JJ, Mann K, Sanz L, Raida M \& Töpfer-Petersen E 1996 The primary structure of BSP-30K, a major lipid-, gelatin-, and heparin-binding glycoprotein of bovine seminal plasma. FEBS Letters 399 147-152. (doi:10.1016/S0014-5793(96)01310-5)

Calvete JJ, Raida M, Gentzel M, Urbanke C, Sanz L \& Töpfer-Petersen E 1997 Isolation and characterization of heparin- and phosphorylcholinebinding proteins of boar and stallion seminal plasma. Primary structure of porcine pB1. FEBS Letters 407 201-206. (doi:10.1016/S0014-5793 (97)00344-X)

Cao E, Chen Y, Cui Z \& Foster PR 2003 Effect of freezing and thawing rates on denaturation of proteins in aqueous solutions. Biotechnology and Bioengineering 82 684-690. (doi:10.1002/bit.10612)
Cormier N \& Bailey JL 2003 A differential mechanism is involved during heparin- and cryopreservation-induced capacitation of bovine spermatozoa. Biology of Reproduction 69 177-185. (doi:10.1095/biolreprod. 102.011056)

D'Amours O, Frenette G, Fortier M, Leclerc P \& Sullivan R 2010 Proteomic comparison of detergent-extracted sperm proteins from bulls with different fertility indexes. Reproduction 139 545-556. (doi:10.1530/ REP-09-0375)

Desnoyers L \& Manjunath P 1992 Major proteins of bovine seminal plasma exhibit novel interactions with phospholipid. Journal of Biological Chemistry 267 10149-10155.

Food and Agricultural Organization of the United Nations Office of Knowledge Exchange, Research and Extension 2011 Chapter 3: current status and options for livestock biotechnologies in developing countries. In Biotechnologies for Agricultural Development: Proceedings of the FAO international technical conference on 'Agricultural Biotechnologies in Developing Countries: Options and opportunities in crops, forestry, livestock, fisheries and agroindustry to face the challenges of food insecurity and climate change' (ABDC-10), pp 123-190. Rome, Italy: FAO. (available at: http://www.fao.org/docrep/014/i2300e/i2300e03.pdf)

Felipe-Pérez YE, Valencia J, Juárez-Mosqueda ML, Pescador N, Roa-Espitia AL \& Hernández-González EO 2011 Cytoskeletal proteins F-actin and b-dystrobrevin are altered by the cryopreservation process in bull sperm. Cryobiology 64 103-109. (doi:10.1016/j.cryobiol.2011.12.004)

Forero-Gonzalez RA, Celeghini ECC, Raphael CF, Andrade AFC, Bressan FF \& Arruda RP 2010 Effects of bovine sperm cryopreservation using different freezing techniques and cryoprotective agents on plasma, acrosomal and mitochondrial membranes. Andrologia 44 154-159. (doi:10.1111/j.1439-0272.2010.01154.x)

Gualtieri R \& Talevi R 2000 In vitro-cultured bovine oviductal cells bind acrosome-intact sperm and retain this ability upon sperm release. Biology of Reproduction 62 1754-1762. (doi:10.1095/biolreprod62.6.1754)

Gualtieri R \& Talevi R 2003 Selection of highly fertilization-competent bovine spermatozoa through adhesion to the fallopian tube epithelium in vitro. Reproduction 125 251-258. (doi:10.1530/rep.0.1250251)

Gwathmey TM, Ignotz GG, Mueller JL, Manjunath P \& Suarez SS 2006 Bovine seminal plasma proteins PDC-109, BSP-A3 and BSP-30-kDa share functional roles in storing sperm in the oviduct. Biology of Reproduction 75 501-507. (doi:10.1095/biolreprod.106.053306)

Hammerstedt RH, Graham JK \& Nolan JP 1990 Cryopreservation of mammalian sperm: what we ask them to survive. Journal of Andrology $\mathbf{1 1}$ 73-88. (doi:10.1002/j.1939-4640.1990.tb01583.x)

Hung PH \& Suarez SS 2012 Alterations to the bull sperm surface proteins that bind sperm to oviductal epithelium. Biology of Reproduction $\mathbf{8 8}$ 1-11. (doi:10.1095/biolreprod.112.099721)

Hunter RHF 1973 Polyspermic fertilization in pigs after tubal deposition of excessive numbers of spermatozoa. Journal of Experimental Zoology $\mathbf{1 8 3}$ 57-64. (doi:10.1002/jez.1401830107)

Kaproth MT, Rycroft HE, Gilbert GR, Abdel-Azim G, Putnam BF, Schnell SA, Everett RW \& Parks JE 2005 Effect of semen thaw method on conception rate in four large commercial dairy heifer herds. Theriogenology 63 2535-2549. (doi:10.1016/j.theriogenology.2004. 11.001)

Laemmli UK 1970 Cleavage of structural proteins during the assembly of the head of bacteriophage T4. Nature 227 680-685. (doi:10.1038/ 227680a0)

Lane ME, Thérien I, Moreau R \& Manjunath P 1999 Heparin and highdensity lipoprotein mediate bovine sperm capacitation by different mechanisms. Biology of Reproduction 60 169-175. (doi:10.1095/ biolreprod60.1.169)

Lefebvre R \& Suarez SS 1996 Effect of capacitation on bull sperm binding to homologous oviductal epithelium. Biology of Reproduction 54 575-582. (doi:10.1095/biolreprod54.3.575)

Lefebvre J, Boileau G \& Manjunath P 2009 Recombinant expression and affinity purification of a novel epididymal human sperm-binding protein, BSPH1. Molecular Human Reproduction 15 105-114. (doi:10.1093/ molehr/gan077)

Lessard C, Siqueira LG, D'Amours O, Sullivan R, Leclerc P \& Palmer C 2011 Infertility in a beef bull due to a failure in the capacitation process. Theriogenology 76 891-899. (doi:10.1016/j.theriogenology.2011. 04.020) 
Manjunath M \& Thérien I 2002 Role of seminal plasma phospholipidbinding proteins in sperm membrane lipid modification that occurs during capacitation. Journal of Reproductive Immunology 53 109-119. (doi:10.1016/S0165-0378(01)00098-5)

Manjunath P, Lefebvre J, Jois PS, Fan J \& Wright MW 2009 New nomenclature for mammalian BSP genes. Biology of Reproduction $\mathbf{8 0}$ 394-397. (doi:10.1095/biolreprod.108.074088)

Moura AA, Koc H, Chapman DA \& Killian GJ 2006 Identification of proteins in the accessory sex gland fluid associated with fertility indexes of dairy bulls: a proteomic approach. Journal of Andrology 27 201-211. (doi:10.2164/jandrol.05089)

Müller P, Erlemann KR, Müller K, Calvete J, Töpfer-Petersen E, Marienfeld K \& Herrmann A 1998 Biophysical characterization of the interaction of bovine seminal plasma protein PDC-109 with phospholipid vesicles. European Biophysics Journal 27 33-41. (doi:10.1007/ s002490050108)

Nauc V \& Manjunath P 2000 Radioimmunoassays for bull seminal plasma proteins (BSP-A1/-A2, BSP-A3, and BSP-30-kilodaltons), and their quantification in seminal plasma and sperm. Biology of Reproduction 63 1058-1066. (doi:10.1095/biolreprod63.4.1058)

Ollero M, Bescós O, Cebrián-Pérez JA \& Muiño-Blanco T 1998 Loss of plasma membrane proteins of bull spermatozoa through the freezingthawing process. Theriogenology 49 547-555. (doi:10.1016/S0093691X(98)00006-5)

Parks JE \& Graham JK 1992 Effects of cryopreservation procedures on sperm membranes. Theriogenology 38 209-222. (doi:10.1016/0093-691X(92) 90231-F)

Parrish JJ, Susko-Parrish J, Winer MA \& First NL 1988 Capacitation of bovine sperm by heparin. Biology of Reproduction 38 1171-1180. (doi:10.1095/biolreprod38.5.1171)

Plante G, Thérien I \& Manjunath P 2012 Characterization of recombinant murine binder of sperm protein homolog 1 and its role in capacitation. Biology of Reproduction 87 (20) 1-11. (doi:10.1095/biolreprod.111. 096644)

Pollard JW, Plante C, King WA, Hansen PJ, Betteridge KJ \& Suarez SS 1991 Fertilizing capacity of bovine sperm may be maintained by binding to oviductal epithelial cells. Biology of Reproduction 44 102-107. (doi:10.1095/biolreprod44.1.102)

Pons-Rejraji H, Bailey JL \& Leclerc P 2009 Cryopreservation affects bovine sperm intracellular parameters associated with capacitation and acrosome exocytosis. Reproduction, Fertility, and Development 21 525-537. (doi:10.1071/RD07170)
Roncoletta M, Morani Eda S, Esper CR, Barnabe VH \& Franceschini PH 2006 Fertility-associated proteins in Nelore bull sperm membranes. Animal Reproduction Science 91 77-87. (doi:10.1016/j.anireprosci. 2005.03.014)

Seidah NG, Manjunath P, Rochemont J, Sairam MR \& Chrétien M 1987 Complete amino acid sequence of BSP-A3 from bovine seminal plasma. Homology to PDC-109 and to the collagen-binding domain of fibronectin. Biochemical Journal 243 195-203.

Suarez SS 2007 Interactions of spermatozoa with the female reproductive tract: inspiration for assisted reproduction. Reproduction, Fertility, and Development 19 103-110. (doi:10.1071/RD06101)

Thomas PG, Ball BA, Miller PG, Brinsko SP \& Southwood L 1994 A subpopulation of morphologically normal, motile spermatozoa attach to equine oviductal epithelial cell monolayers. Biology of Reproduction 51 303-309. (doi:10.1095/biolreprod51.2.303)

Töpfer-Petersen E, Wagner A, Friedrich J, Petrunkina A, Ekhlasi-Hundrieser M, Waberski D \& Drommer W 2002 Function of the mammalian oviductal sperm reservoir. Journal of Experimental Zoology 292 210-215. (doi:10.1002/jez.1157)

Towbin H, Staehelin T \& Gordon J 1979 Electrophoretic transfer of proteins from polyacrylamide gels to nitrocellulose sheets: procedure and some applications. PNAS 76 4350-4354. (doi:10.1073/pnas.76.9.4350)

Vadnais L \& Althouse GC 2011 Characterization of capacitation, cryoinjury, and the role of seminal plasma in porcine sperm. Theriogenology $\mathbf{7 6}$ 1508-1516. (doi:10.1016/j.theriogenology.2011.06.021)

Villemure M, Lazure C \& Manjunath P 2003 Isolation and characterization of gelatin-binding proteins from goat seminal plasma. Reproductive Biology and Endocrinology 28 39. (doi:10.1186/1477-7827-1-39)

Wah DA, Fernández-Tornero C, Sanz L, Romero A \& Calvete JJ 2002 Sperm coating mechanism from the $1.8 \AA$ crystal structure of PDC-109phosphorylcholine complex. Structure 10 505-514. (doi:10.1016/ S0969-2126(02)00751-7)

Watson PF 1995 Recent developments and concepts in the cryopreservation of spermatozoa and the assessment of their post-thawing function. Reproduction, Fertility, and Development 7 871-891. (doi:10.1071/RD9950871)

Received 19 November 2012

First decision 4 January 2013

Revised manuscript received 28 May 2013

Accepted 3 June 2013 